\title{
Economics of Milk Products Manufacturing: A study on State Co-operative Dairy Plant of Balasore District Odisha, India
}

\author{
Mir Miraj Alli ${ }^{1}$ A. K. Chauhan ${ }^{1}$, Danny Franco ${ }^{2}$ and Shyam Prakash Singh ${ }^{3 *}$ \\ ${ }^{1}$ Dairy Economics, Statistics and Management Division, ICAR-National Dairy Research \\ Institute, Karnal-132001, Haryana, India \\ ${ }^{2}$ Division of Agricultural Economics, Indian Agricultural Research Institute, Pusa- 110012, \\ New Delhi, India \\ ${ }^{3}$ Technology and Business Development Division, CSIR-Central Institute of Medicinal and \\ Aromatic Plants, Lucknow-226015, Uttar Pradesh, India \\ *Corresponding author
}

\section{A B S T R A C T}

\begin{tabular}{|l|}
\hline Ke y w o r d s \\
Dairy plant, \\
profitable, \\
Packaging, \\
Milk products, \\
Processing
\end{tabular}

The study conducted at Odisha State Co-operative Milk Producers Federation Ltd. (OMFED) dairy plant of Balasore district, handling capacity 50,000 LPD for the financial year March 2013-April 2014, revealed that among different products manufactured, Sweet Dahi turned out to be the most profitable product $(40.55 \%)$ followed by Sweetened Flavoured Milk (28.7\%) and Toned Milk (24.76\%) whereas Paneer manufacturing turned out to be the lowest profitable $(5.71 \%)$ proposition. There is a need to explore the possibility to increase the profits in Paneer manufacturing by increasing the price of the product or to adopt some suitable steps to use the residual whey for by-products such as whey based beverages, whey powder and in the pharmaceutical industry to bring down the cost. The share of packaging cost of Sweet Dahi was observed higher (28\%) followed by Sweetened Flavoured Milk (22\%) and Rabidi (13\%). The packaging cost of these products seems higher so the management of the plant may look into and search for alternative technologies. Among different products manufactured, Paneer manufacturing turned out to be the lowest profitable. The share of packaging cost of Sweet Dahi was observed higher followed by Sweetened Flavoured Milk and Rabidi. Toned milk contributes about 90 per cent of the total revenue.

\section{Introduction}

During the next few years, till 2030, the demand for dairy products is expected to grow at a rate of 9-12 per cent and industry at a rate of 4-5 per cent in India. Clearly, the Indian industry will struggle to maintain hundred per cent self-sufficiency due to huge local demand, between 160 to 170 million tones of milk that would be required by 2030 (Food and Beverages news, 2014). The industry will have to overhaul to meet ends. With the potential to accommodate imports with home produced dairy products, the Indian industry will present to be a very lucrative market. The dairy sector is a 
dynamic global industry, with steadily growing production trends $(2.2 \%$ annually on average since 2000) which are forecast to continue in the long-term. These trends are driven by an increase in demand for animal proteins that goes along with the population growth and income growth in emerging economies. Consumption of dairy products is consequently expected to increase by 20 per cent or more before 2021 (FAO, 2013). In this context, dairy production and dairy processing clearly appear as industries of utmost importance in contributing to the global challenge of food security today and for decades to come. Dairy products are a major source of cheap and nutritious food to millions of people in India and the only acceptable source of animal protein for large vegetarian segment of Indian population, particularly among the landless, small and marginal farmers and women.

The untapped potential of the dairy sector is immense and opportunity to set up a new dairy venture is great. There is vast potential for the export of dairy products, as the cost of milk production in India being the lowest. In addition to domestic demand, the international demand from Indian dairy products has also shown some buoyancy. Over the past decade, significant transformation took place in the Indian demographic space which led to heightened consumer interest in value added products. This shift in the dynamics of the industry proved beneficial for the manufacturers since margins in value added products are more than double the margins in the liquid milk segment. The profitability in liquid milk space ranges from 4-5 per cent, whereas the profitability in value added products ranges from 12 per cent to 18 per cent, attracting private participation in the industry. As per the industry estimates, the share of value added products in the milk and milk derivatives segment is growing currently at around 25 per cent every year and is expected to grow at the same rate until 2020 (Indian Dairy Industry Report, 2013-14).

To survive in this intense competition, Indian Dairy Industry has to be innovative and cost effective. But the installed capacity of the milk plants is still remaining unutilized thereby resulting in high unit cost of processing. Volume of milk handling and the energy conservation in a milk plant are the two important aspects, which affect the cost of milk processing and products manufacturing. Low cost products can be made available for the consumer only if the plants operate at their full capacity. Unless, the processing cost is controlled effectively, India will not be able to cash the competitive advantage in milk production. Though liberalization and globalization have expanded the dairy market but at the same time stiff challenges have also been posed from different countries as well.

The continuous estimates with respect to economics for manufacturing dairy products are essential for the management to take right decisions for product manufacturing, policy and planning purpose. Few attempts have been made to work out the economics of manufacturing of dairy products in different dairy plants in the country (Mondal, 1999; Singh et al., 2000; Murali, 2001; Chauhan, et al., 2002; Narnaware, 2002 and Feroze, 2005). The present study was an attempt to work out the economics of product manufacturing at Odisha State Co-operative Milk Producers Federation Ltd. (OMFED) dairy plant of Balasore district, handling capacity 50,000 LPD installed capacity, cooperative sector situated in eastern part of India.

\section{Materials and Methods}

Out of the 11 dairy plants under the Odisha State Co-operative Milk Producers Federation 
Ltd. (OMFED), dairy plant of Balasore district having capacity of 50,000 Litres per Day (LPD), which is the largest dairy plant in coastal Odisha in capacity among the four coastal dairy plants, was selected for the study. The wider Product mix, maintenance of detailed data \& records and easy accessibility to data prompted to its selection. The required data for the financial year 2013 - 14 were collected from the records of the milk plant for working out the economics of milk products manufacturing. The milk plant under study was classified into two departments, namely, Main department and Auxiliary department. The former was directly related to the manufacturing of milk products, whereas the later provided the services like steam generation, refrigeration, water supply, maintenance, quality control, effluent treatment plant etc. Items under direct expenses like raw materials, packaging material, fuel and spare parts, etc. were allocated to the products as per their actual use. The detailed data from the records were collected on the various aspects like daily raw milk received with Fat and SNF by the plant during the reference period, price paid for milk, raw material used by different sections of the plant for manufacturing different products, output of different products, salary and other benefits of the staff and contact labourers, fuel used in boilers, generators and other sections, spare parts, sundry items, electricity bills, telephone bills, interest paid on loans other recurring expenditures of the plant, chemicals used for testing of samples in the quality control section, running hours of different machines, capacity of the motors, current and voltage drawn by the motors fitted with different equipments from the log book maintained by different section or units. The milk Fat and milk SNF losses were worked out and the equivalent amounts of losses were added in the cost of raw materials (Belloin, 1988). Depreciation of the building/ machinery and equipments was worked by the straight-line method. The actual amount of interest paid by the plant during the study period was taken into account.

\section{Results and Discussion}

The detailed break-up of cost components of various products into fixed and variable cost, total and per unit costs are presented below.

\section{Cost of Toned Milk (TM)}

Economics of Toned Milk production has been worked out and is displayed in table 1 . Raw materials alone accounted for 93.18 per cent of total expenditure. Next important cost component was refrigeration that accounted for 2.46 per cent of total expenditure followed by cost on packaging material $(2.25 \%)$. Rests of all other costs were less than one per cent individually.

Share of total fixed cost in total cost was only 1.17 per cent where as share of total variable cost was as high as 98.83 per cent in total cost. Cost of Production of TM was worked out to be Rs 24.79 per litre.

\section{Cost of Whole Milk Curd (WMC)}

Next only to Toned Milk, Whole Milk Curd (WMC) is an important product in the product mix of tire dairy plant. Total 832.36 million tons of Whole Milk Curd was manufactured during 2013-2014. The cost of manufacture of Whole Milk Curd is set out in table 2. The table revealed that the cost of manufacture of Whole Milk Curd was Rs 15.71 per 500 g pouch. Share of raw materials accounted for 89.15 per cent of the total cost followed by packaging material $(4.77 \%)$, depreciation and interest on building and machineries (1.50\%) and refrigeration $(1.50 \%)$. Labour contributed 1.08 per cent of total cost. Steam added 0.80 per cent to the total cost. 
Table.1 Component-wise cost of toned milk manufacturing (2013-14)

\begin{tabular}{|c|l|c|c|}
\hline SI. No. & Cost Components & Unit Cost (Rs. / Lit.) & Per cent \\
\hline $\mathbf{1}$ & Raw Material & 23.10 & 93.18 \\
\hline $\mathbf{2}$ & Labour & 00.07 & 00.28 \\
\hline $\mathbf{3}$ & Electricity & 00.04 & 00.16 \\
\hline $\mathbf{4}$ & Water & 00.01 & 00.04 \\
\hline $\mathbf{5}$ & Steam & 00.12 & 00.48 \\
\hline $\mathbf{6}$ & Refrigeration & 00.61 & 02.46 \\
\hline $\mathbf{7}$ & Quality control & 00.05 & 00.20 \\
\hline $\mathbf{8}$ & Packaging material & 00.50 & 02.02 \\
\hline $\mathbf{9}$ & Administration and supervision & 00.04 & 00.16 \\
\hline $\mathbf{1 0}$ & Depreciation, interest on building and machineries & 00.08 & 00.32 \\
\hline $\mathbf{1 1}$ & Miscellaneous* & 00.17 & 00.69 \\
\hline & Total cost & $\mathbf{2 4 . 7 9}$ & $\mathbf{1 0 0 . 0 0}$ \\
\hline
\end{tabular}

Miscellaneous* includes expenses incurred in watch and ward, Effluent Treatment Plant, Clean in Place etc.

Table.2 Component-wise cost of whole milk curd manufacturing (2013-14)

\begin{tabular}{|c|l|c|c|}
\hline Sl. No. & Cost Components & $\begin{array}{c}\text { Unit Cost } \\
\text { (Rs./ 500g Pouch) }\end{array}$ & Percentage \\
\hline $\mathbf{1}$ & Raw material & 14.005 & 89.15 \\
\hline $\mathbf{2}$ & Labour & 00.170 & 01.08 \\
\hline $\mathbf{3}$ & Electricity & 00.025 & 00.16 \\
\hline $\mathbf{4}$ & Water & 00.005 & 00.03 \\
\hline $\mathbf{5}$ & Steam & 00.125 & 00.79 \\
\hline $\mathbf{6}$ & Refrigeration & 00.235 & 01.50 \\
\hline $\mathbf{7}$ & Quality control & 00.030 & 00.19 \\
\hline $\mathbf{8}$ & Packaging material & 00.750 & 04.77 \\
\hline $\mathbf{9}$ & Administration and supervision & 00.030 & 00.16 \\
\hline $\mathbf{1 0}$ & Depreciation, interest on building \& machineries & 00.235 & 01.50 \\
\hline $\mathbf{1 1}$ & Miscellaneous & 00.105 & 00.67 \\
\hline & Total & $\mathbf{1 5 . 7 1}$ & $\mathbf{1 0 0 . 0 0}$ \\
\hline
\end{tabular}


Table.3 Component-wise cost of paneer manufacturing (2013-14)

\begin{tabular}{|c|l|c|c|}
\hline Sl. No. & Cost Components & Unit Cost (Rs./Kg) & Percentage \\
\hline $\mathbf{1}$ & Raw material & 190.99 & 96.46 \\
\hline $\mathbf{2}$ & Labour & 002.88 & 01.45 \\
\hline $\mathbf{3}$ & Electricity & 000.30 & 00.15 \\
\hline $\mathbf{4}$ & Water & 000.05 & 00.03 \\
\hline $\mathbf{5}$ & Steam & 000.26 & 00.13 \\
\hline $\mathbf{6}$ & Refrigeration & 000.45 & 00.22 \\
\hline $\mathbf{7}$ & Quality control & 000.31 & 00.16 \\
\hline $\mathbf{8}$ & Packaging material & 001.00 & 00.51 \\
\hline $\mathbf{9}$ & Administration and supervision & 000.27 & 00.14 \\
\hline $\mathbf{1 0}$ & Depreciation, interest on building \& machineries & 000.38 & 00.19 \\
\hline $\mathbf{1 1}$ & Miscellaneous & 001.11 & 00.56 \\
\hline & Total & $\mathbf{1 9 8 . 0 0}$ & $\mathbf{1 0 0 . 0 0}$ \\
\hline
\end{tabular}

Table.4 Component-wise cost of sweet dahi manufacturing (2013-14)

\begin{tabular}{|c|l|c|c|}
\hline \multicolumn{1}{|c|}{ Cost components } & Unit Cost (Rs./ 80 g cup) & Percentage \\
\hline Sl. No. & & 2.92 & 67.36 \\
\hline $\mathbf{1}$ & Raw material & 0.06 & 01.37 \\
\hline $\mathbf{2}$ & Labour & 0.01 & 00.24 \\
\hline $\mathbf{3}$ & Electricity & 0.01 & 00.06 \\
\hline $\mathbf{4}$ & Water & 0.02 & 00.55 \\
\hline $\mathbf{5}$ & Steam & 0.04 & 00.87 \\
\hline $\mathbf{6}$ & Refrigeration & 0.01 & 00.26 \\
\hline $\mathbf{7}$ & Quality control & 1.20 & 27.68 \\
\hline $\mathbf{8}$ & Packaging material & 0.01 & 00.22 \\
\hline $\mathbf{9}$ & Administration and supervision & 0.02 & 00.54 \\
\hline $\mathbf{1 0}$ & Depreciation, Interest on Building \& Machineries & 0.04 & 00.89 \\
\hline $\mathbf{1 1}$ & Miscellaneous & $\mathbf{4 . 3 4}$ & $\mathbf{1 0 0 . 0 0}$ \\
\hline
\end{tabular}

Table.5 Component-wise cost of rabidi manufacturing (2013-14)

\begin{tabular}{|c|l|c|c|}
\hline \multicolumn{1}{|c|}{ Cost Components } & Unit Cost(Rs./80 g cup) & Percentage \\
\hline Sl. No. & \multicolumn{1}{|c|}{ (1) } & 82.50 \\
\hline $\mathbf{1}$ & Raw material & 0.17 & 01.80 \\
\hline $\mathbf{2}$ & Labour & 0.01 & 00.20 \\
\hline $\mathbf{3}$ & Electricity & 0.05 & 00.05 \\
\hline $\mathbf{4}$ & Water & 0.02 & 00.20 \\
\hline $\mathbf{5}$ & Steam & 0.04 & 00.40 \\
\hline $\mathbf{6}$ & Refrigeration & 0.02 & 00.20 \\
\hline $\mathbf{7}$ & Quality control & 1.20 & 13.30 \\
\hline $\mathbf{8}$ & Packaging material & 0.01 & 00.20 \\
\hline $\mathbf{9}$ & Administration and supervision & 0.05 & 00.50 \\
\hline $\mathbf{1 0}$ & Depreciation, interest on building \& machineries & 0.06 & 00.70 \\
\hline $\mathbf{1 1}$ & Miscellaneous & $\mathbf{9 . 0 5}$ & $\mathbf{1 0 0 . 0 0}$ \\
\hline & Total & & \\
\hline
\end{tabular}


Table.6 Component-wise cost of butter milk sip manufacturing (2013-14)

\begin{tabular}{|c|l|c|c|}
\hline SI. No. & \multicolumn{1}{|c|}{ Cost Components } & $\begin{array}{c}\text { Unit Cost } \\
\text { (Rs. / 250 ml pouch) }\end{array}$ & Percentage \\
\hline $\mathbf{1}$ & Raw Material & 3.31 & 81.88 \\
\hline $\mathbf{2}$ & Labour & 0.09 & 02.29 \\
\hline $\mathbf{3}$ & Electricity & 0.01 & 00.19 \\
\hline $\mathbf{4}$ & Water & 0.03 & 00.07 \\
\hline $\mathbf{5}$ & Steam & 0.03 & 00.62 \\
\hline $\mathbf{6}$ & Refrigeration & 0.15 & 03.77 \\
\hline $\mathbf{7}$ & Quality Control & 0.01 & 00.19 \\
\hline $\mathbf{8}$ & Packaging Material & 0.40 & 09.89 \\
\hline $\mathbf{9}$ & Administration And Supervision & 0.01 & 00.19 \\
\hline $\mathbf{1 0}$ & Depreciation, interest on building \& machineries & 0.01 & 00.25 \\
\hline $\mathbf{1 1}$ & Miscellaneous & 0.03 & 00.68 \\
\hline & Total & $\mathbf{4 . 0 5}$ & $\mathbf{1 0 0 . 0 0}$ \\
\hline
\end{tabular}

Table.7 Component-wise cost of sweetened flavoured milk manufacturing

\begin{tabular}{|c|l|c|c|}
\hline SI . No & Cost components & Unit Cost $\mathbf{( R s . / 2 0 0 ~} \mathbf{~ m l})$ & Percentage \\
\hline $\mathbf{1}$ & Raw material & 5.894 & 61.50 \\
\hline $\mathbf{2}$ & Labour & 0.410 & 03.60 \\
\hline $\mathbf{3}$ & Electricity & 0.408 & 03.60 \\
\hline $\mathbf{4}$ & Water & 0.016 & 00.18 \\
\hline $\mathbf{5}$ & Steam & 0.068 & 00.60 \\
\hline $\mathbf{6}$ & Quality control & 0.018 & 00.20 \\
\hline $\mathbf{7}$ & Packaging material & 02.00 & 22.40 \\
\hline $\mathbf{8}$ & Administration and supervision & 0.016 & 00.20 \\
\hline $\mathbf{9}$ & Interest and Depreciation & 0.014 & 00.20 \\
\hline $\mathbf{1 0}$ & Miscellaneous & 0.066 & 00.70 \\
\hline & Total & $\mathbf{0 8 . 9 1}$ & $\mathbf{1 0 0 . 0 0}$ \\
\hline
\end{tabular}

Table.8 Profitability in different dairy products (2013-14)

\begin{tabular}{|l|c|c|c|c|}
\hline Products & $\begin{array}{c}\text { Price Received By } \\
\text { Plant }\end{array}$ & $\begin{array}{c}\text { Unit Cost Of } \\
\text { Manufacturing }\end{array}$ & $\begin{array}{c}\text { Profit } \\
\text { Margin }\end{array}$ & $\begin{array}{c}\text { Profit } \\
\text { (\%) }\end{array}$ \\
\hline Paneer (kg) & 210.00 & 198.00 & 12.00 & 05.71 \\
\hline Toned Milk (litre) & 032.95 & 024.79 & 08.16 & 24.76 \\
\hline BMS (250 ml) & 005.00 & 004.05 & 00.95 & 19.00 \\
\hline Rabidi $\mathbf{( 8 0}$ g) & 011.20 & 009.05 & 02.15 & 19.22 \\
\hline WMC (500 g) & 020.26 & 015.71 & 04.55 & 22.46 \\
\hline Sweet dahi $\mathbf{( 8 0}$ g) & 007.30 & 004.34 & 02.96 & 40.55 \\
\hline SFM (200 ml) & 012.50 & 008.91 & 03.59 & 28.72 \\
\hline
\end{tabular}


Total fixed cost was found to be 2.33 per cent whereas total variable cost was 97.67 per cent of the total cost.

\section{Cost of paneer}

The total quantity of Paneer produced during the study period was 88.45 million tons. Table 3 revealed that the cost of production of Paneer turned out to be Rs 198 per kg. The contribution of total fixed cost and total variable cost to the total cost were 0.89 per cent and 99.11 percent respectively. In the total cost, processing cost was 3.54 per cent and the rest was raw materials cost. Other than milk, citric acid, calcium lactate for coagulation had a share of 0.7 per cent in the total raw material cost. In processing cost, the labour cost contributed 1.45 per cent, miscellaneous 0.56 per cent and packaging material costs 0.51 per cent of the total cost. The shares of steam, depreciation on equipments and buildings and interest on loans, electricity were also significant.

\section{Cost of Sweet Dahi}

Sweet dahi in the vicinity area known as Mitha Dahi, standardized milk having fat content $4.5 \%$ and SNF $8.5 \%$ was used for manufacturing of Sweet Dahi. The compositional cost figures to manufacture Sweet Dahi are given in Table 4. The cost of manufacturing of sweet dahi was Rs 4.34 per $80 \mathrm{~g}$ cup. The processing cost was 32.64 per cent of the total cost. In the processing cost, the packaging cost was highest (27.68\%) followed by expenses on labour $(1.37 \%)$ miscellaneous $(0.89 \%)$, refrigeration $(0.87$ $\%)$, steam $(0.54 \%)$ and depreciation and interest $(0.54 \%)$. Other cost components were negligible. Total fixed cost and total variable cost contributed 1.65 and 98.35 per cent to the total cost. The plant incurred Rs 70.82 lakhs in sweet dahi manufacturing and the total production was 130.67 million tons.

\section{Cost of Rabidi}

A perusal of Table 5 revealed that Rabidi manufacturing cost was Rs 9.05 per 80 gram cup. Processing activities added cost by Rs 1.58 to raw materials of Rs.7.47. Processing cost thus worked out to be 17.48 per cent of the total cost. Break-up of processing cost into its constituents shows that expense on packaging was 13.26 per cent, labour accounted for 1.84 per cent followed by miscellaneous (0.65\%), depreciation and interest $(0.54 \%)$. Segregation of total cost into fixed costs and variable costs indicated that total fixed cost was only 1.35 per cent and the rest was the share of total variable cost

\section{Cost of Butter Milk Sip (BMS)}

The cost of Butter Milk Sip (BMS) production is presented in Table 6 it is evident from the table that the cost of Butter Milk Sip manufacturing was Rs 4.05 per $250 \mathrm{ml}$ pouch out of which raw materials alone accounted for Rs 3.31 per $250 \mathrm{ml}$ of the product. Packaging cost accounted for Rs 9.89 per cent, refrigeration 3.77 per cent, labour cost to make the product was 2.29 per cent followed by refrigeration $(3.77 \%)$, miscellaneous $(0.68 \%)$ and steam $(0.62 \%)$. Total fixed cost and total variable cost were 1.12 per cent and 98.88 per cent respectively.

\section{Cost of Sweetened Flavoured Milk (SFM)}

Sweetened Flavoured Milk (SFM) is the second most important product line among the fluid milk family. Table 7 gave the details on the cost components for Sweetened Flavoured Milk. It is revealed that per $200 \mathrm{ml}$ bottle of Sweetened Flavoured Milk costs Rs 8.91 out of that 66.15 per cent is contributed by raw materials. Next comes packaging $(22.45 \%)$, labour (4.60\%), and electricity (4.58\%). As bottle sterilizer is used after the manufacturing process, it leads to more electricity consumption. Disposable bottle 
costs about Rs. 2.00 per $200 \mathrm{ml}$ Sweetened Flavoured Milk, which leads to higher packaging cost. The share of other cost contributes less than one per cent to the total cost.

\section{Profitability in different dairy products}

Information regarding the profit margins of a dairy plant is of paramount importance as it gives direction to the management for decision making about the product mix. Profitability of the dairy products was worked out by comparing the unit cost with the unit price received by the plant for sale of different dairy products. The unit cost of manufacturing different products was deducted from the net price received by the plant.

Profitability of the dairy products is presented in Table 8. The information contained in the table reveals that Sweet Dahi turned out to be the most profitable product $(40.55 \%)$ followed by Sweetened Flavoured Milk (28.72\%), toned milk (24.76\%), and WMC (22.46\%). Rabidi and Butter Milk Sip have the profitability of 19.22 per cent and 19 per cent respectively. Among different products manufactured, paneer manufacturing turned out to be the lowest profitable proposition (yield $5.71 \%$ profit).

In conclusions the competition and quality aspect have limited the profitability of the milk plants. Among different products manufactured, Paneer manufacturing turned out to be the lowest profitable proposition (yield 5\% profit), Hence there is need to explore the possibility to increase the profits in Paneer manufacturing by increasing the price of the product or to adopt some suitable steps to use the residual whey for by products such as whey based beverages, whey powder and in pharmaceutical industry to bring down the cost. The share of packaging cost of Sweet
Dahi was observed higher (28\%) followed by Sweetened Flavoured Milk (22\%) and Rabidi (13\%). The packaging cost of these products seems higher so the management of the plant may look into and search for alternative technologies. As toned milk contributes about 90 per cent of the total revenue, some of the resources of this product can be shifted to higher profitable products if demand is there

\section{References}

Belloin, J.C. 1988. Milk and Dairy Products, Production and Processing Costs, Food and Agriculture Organization Animal and Health Paper, 62: 23-24.

Chauhan, A.K., Rajvir, S., Kalra, K.K. and Raina, B.B. 2002. Economics of Milk Processing and Manufacture of Dairy Products in a Dairy Plant. A Report on Research Programme. Division of Dairy Economics, Statistics and Management, National Dairy Research Institute, Karnal, Haryana.

Feroze, S.M. 2005. Economics of Manufacture of Dairy Products in a Cooperative Dairy Plant in Haryana. M.Sc. Dissertation, National Dairy Research Institute, Karnal, Haryana.

Food and Agriculture Organization (FAO) of the United Nations (2013) and Organization for Economic Cooperation and Development (OECD). Corrigenda to OECD publications may be found online at: www.oecd.org/publishing/corrigenda.

Food and Beverages News 2013-14. www.fnbnews.com.

Indian Dairy Industry Report 2013-14. www allindiadairy.com

Mondal, B. 1999. Economic Analysis of Indigenous Dairy Products in Burdwan District of West Bengal. M.Sc. Dissertation, National Dairy Research Institute, Karnal, Haryana.

Murali, P. (2001). Economics of Milk 
Processing and Manufacture of Dairy Products on a Co-operative Dairy Plant in Tamil Nadu. M.Sc. Dissertation, National Dairy Research Institute, Karnal, Haryana.

Naranware, G. 2002. Economics of Manufacturing of Dairy Products in a Plant. M.Sc. Dissertation, National Dairy Research Institute, Karnal, Haryana.
OMFED (Odisha State Cooperative Milk Producers' Federation Ltd.) D-2, Sahid Nagar, Bhubaneswar-751 007.www.omfed.com

Singh, K., Chauhan, A.K. and Rajvir, S. 2000. Economics of Khoa and Chhana Based Milk Products in Karnal Market. Haryana Economic Journal, 20 (1\&2): 143-150.

\section{How to cite this article:}

Mir Miraj Alli, A. K. Chauhan, Danny Franco and Shyam Prakash Singh. 2020. Economics of Milk Products Manufacturing: A study on State Co-operative Dairy Plant of Balasore District Odisha, India. Int.J.Curr.Microbiol.App.Sci. 9(08): 3671-3679.

doi: https://doi.org/10.20546/ijcmas.2020.908.424 